\title{
The Prognostic Role and Relationship between E2F1 and SV40 in Diffuse Large B-Cell Lymphoma of Egyptian Patients
}

\author{
Rehab M. Samaka, Hayam A. Aiad, Mona A. Kandil, Nancy Y. Asaad, and Nanes S. Holah \\ Pathology Department, Faculty of Medicine, Menoufia University, Shebin El-Kom, Egypt \\ Correspondence should be addressed to Rehab M. Samaka; rehabsamaka@yahoo.com
}

Received 6 April 2015; Revised 26 August 2015; Accepted 14 September 2015

Academic Editor: Ekaterina S. Jordanova

Copyright ( 2015 Rehab M. Samaka et al. This is an open access article distributed under the Creative Commons Attribution License, which permits unrestricted use, distribution, and reproduction in any medium, provided the original work is properly cited.

\begin{abstract}
Diffuse large B-cell lymphoma (DLBCL) is the most common type of lymphomas worldwide. The pathogenesis of lymphomas is not yet well understood. SV40 induces malignant transformation by the large T-antigen (L-TAG) and promotes transformation by binding and inactivating $\mathrm{p} 53$ and $\mathrm{pRb}$. L-TAG can bind pRb promoting the activation of the E2F1 transcription factor, thus inducing the expression of genes required for the entry to the $S$ phase and leading to cell transformation. This immunohistochemical study was conducted to assess the prognostic role and relationship of SV40 L-TAG and E2F1 in diffuse large B-cell lymphoma (DLBCL) of Egyptian patients. This retrospective study was conducted on 105 tissue specimens including 20 follicular hyperplasia and 85 DLBCL cases. SV40 L-TAG was identified in 3/85 (4\%) of DLBCL. High Ki-67 labeling index (Ki-67 LI) and apoptotic count were associated with high E2F1 expression ( $p<0.001$ for all). No significant association was reached between E2F1 and SV40. E2F1 expression proved to be the most and first independent prognostic factor on overall survival of DLBCL patients $(\mathrm{HR}=5.79,95 \%$ $\mathrm{CI}=2.3-14.6$, and $p<0.001$ ). Upregulation of E2F1 has been implicated in oncogenesis, prognosis, and prediction of therapeutic response but is not seemingly to have a relationship with the accused SV40.
\end{abstract}

\section{Introduction}

Non-Hodgkin's lymphoma (NHL) is the third common malignancy out of all malignances of Egyptian patients; it is of high rank among cancers in each sex, where it accounts for $8.4 \%$ of estimated incidence with 8.7 age standardized rate (ASR) per 100.000 [1]. In Egypt, NHL represents a major health problem as its rates are one of the highest in the world [2]. Diffuse large B-cell lymphoma (DLBCL) is the most common lymphoma worldwide [1].

Alarmingly, Simian virus (SV40) induces malignant transformation in rodents and human cells. This transformation is induced by the large T-antigen (L-TAG), known to promote transformation by binding and inactivating tumor suppressor genes, such as p53 and pRb [3]. Over the years, an increasing number of reports have suggested that SV40 causes specific tumor types, such as mesothelioma, brain, and bone tumors [4]. L-TAG can bind $\mathrm{pRb}$ promoting the activation of the E2F1 transcription factor, thus inducing the expression of genes required for the entry to the $S$ phase [3].
Few studies have shown the presence of SV40 in lymphomas [4]. Nevertheless, SV40 could be taken into consideration for a putative role in human lymphomagenesis, alone or in combination with additional events, such as a transcription factor E2F1.

E2F is a family of transcription factors that regulate the expression of genes involved in a wide range of cellular processes, including cell-cycle progression, DNA repair, differentiation, and apoptosis [5]. E2F1, the founding member of the family, induces proliferation; both Rb-deficiency and ectopic expression of E2F1 in normal cells lead to high level of apoptosis owing to its ability to activate a large number of proapoptotic genes through a plethora of distinct apoptotic mechanisms [6]. However, the information about the role of E2F1 in human malignancy as depicted from its expression in relationship to tumor kinetic parameters and clinicopathological features is limited and incomplete.

The present immunohistochemical (IHC) study was conducted to assess the role and relationship of SV40 L-TAG and E2F1 in DLBCL of Egyptian patients, get a hint of whether 
SV40 and E2F1 are coplayers in this malignancy or not, and correlate the results with the standard clinicopathological and survival data.

\section{Materials and Methods}

2.1. Studied Population. This retrospective case control study was conducted on 105 archival cases, including 85 DLBCL cases and 20 reactive follicular hyperplasia cases that were used as a control group. They were diagnosed in Pathology Department, Faculty of Medicine, Menoufia University, between January 2003 and December 2007. Written consent forms approved by The Committee of Human Rights in Research in Menoufia University were obtained from studied cases and control subjects before study initiation. Cases were newly diagnosed with no previous treatment taken.

2.2. Clinical Features. Staging was evaluated according to Ann-Arbor staging system and then the cases were divided into an early stage, by lumping stages I and II of the tumor, and an advanced stage, by lumping stages III and IV of the tumor. Revised international prognostic index (R-IPI) was calculated and the final scores stratified the DLBCL patients into 3 distinct prognostic groups [7]. For statistical purpose this score was simplified as $0-2$ indicating good R-IPI and 3-5 indicating poor R-IPI. Age adjusted IPI (AAIPI) was applied separately in patients younger than or equal to 60 years (AAIPI < 60) and those older than 60 years (AAIPI > $60)$ to identify 3 risk groups for each category [8].

2.3. Histopathological Features. The hematoxylin and eosin (H\&E) stained sections were evaluated for the presence and percentage of spontaneous coagulative tumor necrosis. Mitotic and apoptotic figures were counted in 10 randomly selected cellular fields under high power magnification $(\times 400)$ and they were used as dichotomous covariant in the statistical analysis according to the median value for apoptosis and 25 for mitotic count [9]. The Ki-67 labeling index (Ki-67 LI) was determined using a semiquantitative visual approach and expressed as the percentage of $\mathrm{Ki}-67$ positive malignant cells among a total number of 1000 malignant cells, at high power magnification [10]. Fifty percent cutoff point was applied to discriminate between low and high Ki-67 LI [11]. Scoring was carried out using an Olympus CH2 light microscope (Tokyo, Japan) with a wide angle (field size of $0.274 \mathrm{~mm}^{2}$ and field diameter of $0.59 \mathrm{~mm}^{2}$ ).

2.4. SV40 L-TAG and E2F1 Immunostaining Procedure. Five-micrometer-thick sections were cut from the paraffinembedded blocks, deparaffinized in xylene, and rehydrated in a graded alcohol series. Epitope retrieval: the preferred method for SV40 is the use of Heat Induced Epitope Retrieval (HIER) techniques using Cell Marque's Trilogy (Cat. number 920P-04, Cell Marque, 6600 Sierra College Boulevard, Rocklin, CA 95677, USA) and followed by cooling at room temperature. For E2F1 epitope retrieval the tissue sections are boiled in $1 \mathrm{mM}$ EDTA, $\mathrm{pH}$ 8.0. The slides were incubated overnight at $4^{\circ} \mathrm{C}$ with mouse monoclonal SV40
L-TAG Ab-2 with 1:100 as optimal dilution (Cat. number 351-14, Cell Marque, 6600 Sierra College Boulevard, Rocklin, CA 95677, USA). Positive control slides of SV40 infected renal tissues were used (Cat. number 351S, Thermo Scientific, Lab Vision Corporation, 46360 Fremont Boulevard, Fremont, CA 94538-6406, USA). The slides were incubated over night at $4^{\circ} \mathrm{C}$ with mouse monoclonal E2F1 with 1:200 as optimal dilution (Cat. number MS-879-P0Ab-2, Thermo Scientific, Lab Vision Corporation, 46360 Fremont Boulevard, Fremont, CA 94538-6406, USA). Breast carcinoma was used as a positive control. The detection kit used was ultravision detection system antipolyvalent HRP/DAB (ready to use) (Cat. number TP-015-HD, Thermo Scientific, Lab Vision Corporation, 46360 Fremont Boulevard, Fremont, CA 94538-6406, USA). The reaction was visualized by an appropriate substrate/chromogen (Diaminobenzidine, DAB) reagent with Mayer haematoxylin as a counterstain.

2.5. Assessment of SV40 and E2F1 Immunostained Slides. Positive SV40 expression is assigned when any number of cells shows true nuclear staining regardless of absence or presence of concomitant cytoplasmic staining while only cytoplasmic staining does not assign any positivity [12]. Evaluation of E2F-1 expression is based on the proportion of labeled nuclei either low E2F1 expression $(\leq 10 \%)$ or high expression (>10\%) [13]. Unintentional bias was prevented by coding patient tissue samples so that IHC analysis was done without knowledge of the patients' outcome and tumor characteristics. Assessment of slides was done by two of the authors (Rehab M. Samaka and Nanes S. Holah) separately.

2.6. Statistical Analysis. Statistical analysis was performed using SPSS "Statistical Package for the Social Science" program for windows, version 17, SPSS, Inc., Chicago, Illinois, USA. All factors were used as dichotomous covariates in the statistical analysis. To test whether these variables differed according to clinicopathological parameters and biological markers, the Fisher exact (FE), $\chi^{2}$ test, Mann-Whitney test, and Student's $t$-test were used. Log-rank and Cox regression analysis were used for life-table assessment. All $p$ values were two-sided; $p$ values of $<0.05$ were considered statistically significant. Kaplan-Meier plots and hazard function curves were used to visualize the survival distribution.

\section{Results}

(i) Clinicopathological data of DLBCL cases studied are shown in Table 1.

(ii) SV40 expression in reactive lymphoid hyperplasia and DLBCL cases is as follows.

(a) Negative expression of SV40 was noted in all reactive lymphoid hyperplasias (Figure 1(a)). Nuclear positivity for SV40 was identified in only $4 \%$ of DLBCL cases (3/85) (Figure 2).

(b) The profiles of SV40 positive and negative DLBCL cases are shown in Table 2. 
TABLE 1: Clinicopathological characteristics of DLBCL cases studied.

\begin{tabular}{|c|c|}
\hline Variables & $\begin{array}{c}\text { DLBCL } \\
(n=85) \\
\text { No }(\%)\end{array}$ \\
\hline \multicolumn{2}{|l|}{ Age } \\
\hline $\bar{x} \pm \mathrm{SD}$ & $54.31 \pm 16.07$ \\
\hline Median & 56.0 \\
\hline Range & $2.0-87.0$ \\
\hline$<60$ & $49(58)$ \\
\hline$\geq 60$ & $36(42)$ \\
\hline \multicolumn{2}{|l|}{ Gender } \\
\hline Male & $42(49)$ \\
\hline Female & $43(51)$ \\
\hline \multicolumn{2}{|c|}{ Primary site of involvement } \\
\hline Nodal & $56(66)$ \\
\hline Extranodal & $29(34)$ \\
\hline \multicolumn{2}{|c|}{ Number of involved extranodal sites } \\
\hline 0 & $47(55)$ \\
\hline $1-2$ & $32(38)$ \\
\hline$>2$ & $6(7)$ \\
\hline \multicolumn{2}{|l|}{ Status } \\
\hline Generalized & $16(29)$ \\
\hline Localized & $40(71)$ \\
\hline \multicolumn{2}{|l|}{ Size $(\mathrm{cm})$} \\
\hline$\leq 10$ & $74(87)$ \\
\hline$>10$ & $11(13)$ \\
\hline \multicolumn{2}{|l|}{ Stage grouping } \\
\hline Early & $48(56)$ \\
\hline Advanced & $37(44)$ \\
\hline \multicolumn{2}{|l|}{ PS } \\
\hline$<2$ & $14(16)$ \\
\hline$\geq 2$ & $71(84)$ \\
\hline \multicolumn{2}{|l|}{ B symptoms } \\
\hline Present & $51(60)$ \\
\hline Absent & $34(40)$ \\
\hline \multicolumn{2}{|l|}{$\mathrm{LDH}$} \\
\hline Normal & $11(13)$ \\
\hline Elevated & $74(87)$ \\
\hline \multicolumn{2}{|c|}{ Prognostic group of R-IPI } \\
\hline Good & $29(34)$ \\
\hline Poor & $56(66)$ \\
\hline \multicolumn{2}{|c|}{ Risk groups of AAIPI $\geq 60$} \\
\hline Low & $6(7)$ \\
\hline Intermediate & $16(19)$ \\
\hline High & $17(20)$ \\
\hline \multicolumn{2}{|c|}{ Risk groups of AAIPI $<60$} \\
\hline Low & $17(20)$ \\
\hline Intermediate & $11(13)$ \\
\hline High & $18(21)$ \\
\hline \multicolumn{2}{|l|}{ Type of DLBCL } \\
\hline Germinal & $49(57.6)$ \\
\hline Nongerminal & $36(42.4)$ \\
\hline \multicolumn{2}{|l|}{ Necrosis } \\
\hline Present & $14(16)$ \\
\hline Absent & $71(84)$ \\
\hline $\bar{x} \pm \mathrm{SD}$ & $34.3 \pm 22.4$ \\
\hline Range & $10.0-0.80$ \\
\hline
\end{tabular}

TABle 1: Continued.

\begin{tabular}{lc}
\hline Variables & $\begin{array}{c}\text { DLBCL } \\
(n=85) \\
\text { No }(\%)\end{array}$ \\
\hline $\begin{array}{l}\text { Mitosis } \\
\bar{x} \pm \text { SD } \\
\text { Range }\end{array}$ & $22.5 \pm 9.5$ \\
$\quad$ Media & $6.0-46.0$ \\
Ki-67 LI & 21.0 \\
$\quad<50$ & \\
$\quad \geq 50$ & $50(59)$ \\
Apoptosis & $35(41)$ \\
$\quad \bar{x} \pm$ SD & $13.5 \pm 6.4$ \\
$\quad$ Range & $3.0-31.0$ \\
$\quad$ Median & 13.0 \\
\hline R-IPI: revised international prognostic index; AAIPI: age adjusted interna- \\
tional prognostic index. \\
PS: performance status; LDH: lactate dehydrogenase; Ki-67 LI: Ki-67 labeling \\
index. \\
DLBCL: diffuse large B-cell lymphoma.
\end{tabular}

(iii) E2F1 expression in reactive follicular hyperplasia and DLBCL cases is as follows.

(a) All reactive follicular hyperplasia cases showed nuclear E2F1 staining with variable percentages of positivity. The topography of positive lymphocytes was distributed in the germinal centers and in the interfollicular areas with complete negativity in the mantle zone lymphocytes (Figure 3). Low E2F1 expression $(\leq 10 \%)$ was detected in $15 / 20$ cases $(75 \%)$, while high E2F1 expression $(>10 \%)$ was detected in 5/20 (25\%) of them.

(b) All DLBCL cases studied showed positive E2F1 expression. Regarding DLBCL cases, high E2F1 expression $(>10 \%)$ (Figure $4(\mathrm{a})$ ) presented in $44 / 85$ of cases (52\%), while low E2F1 expression $(\leq 10 \%)$ (Figure $4(\mathrm{~b})$ ) presented in $41 / 85$ of cases $(48 \%)$.

(iv) Relationship of E2F1 expression in DLBCL cases studied with the clinicopathological features and presence of SV40 is shown in Table 3.

There was a highly significant difference between low and high E2F1 expression in DLBCL cases regarding the age and age grouping as the lower numerical values of age had associated with high E2F1 expression $(p=0.001$ and $p=$ 0.02 , resp.). Numerous mitoses, high Ki-67 LI, and an abundant number of apoptotic counts were significantly associated with DLBCL cases with high E2F1 expression $(p<0.001$ for all). There was a significant difference between low and high E2F1 expression in DLBCL cases regarding the risk groups of AAIPI $<60$, as 

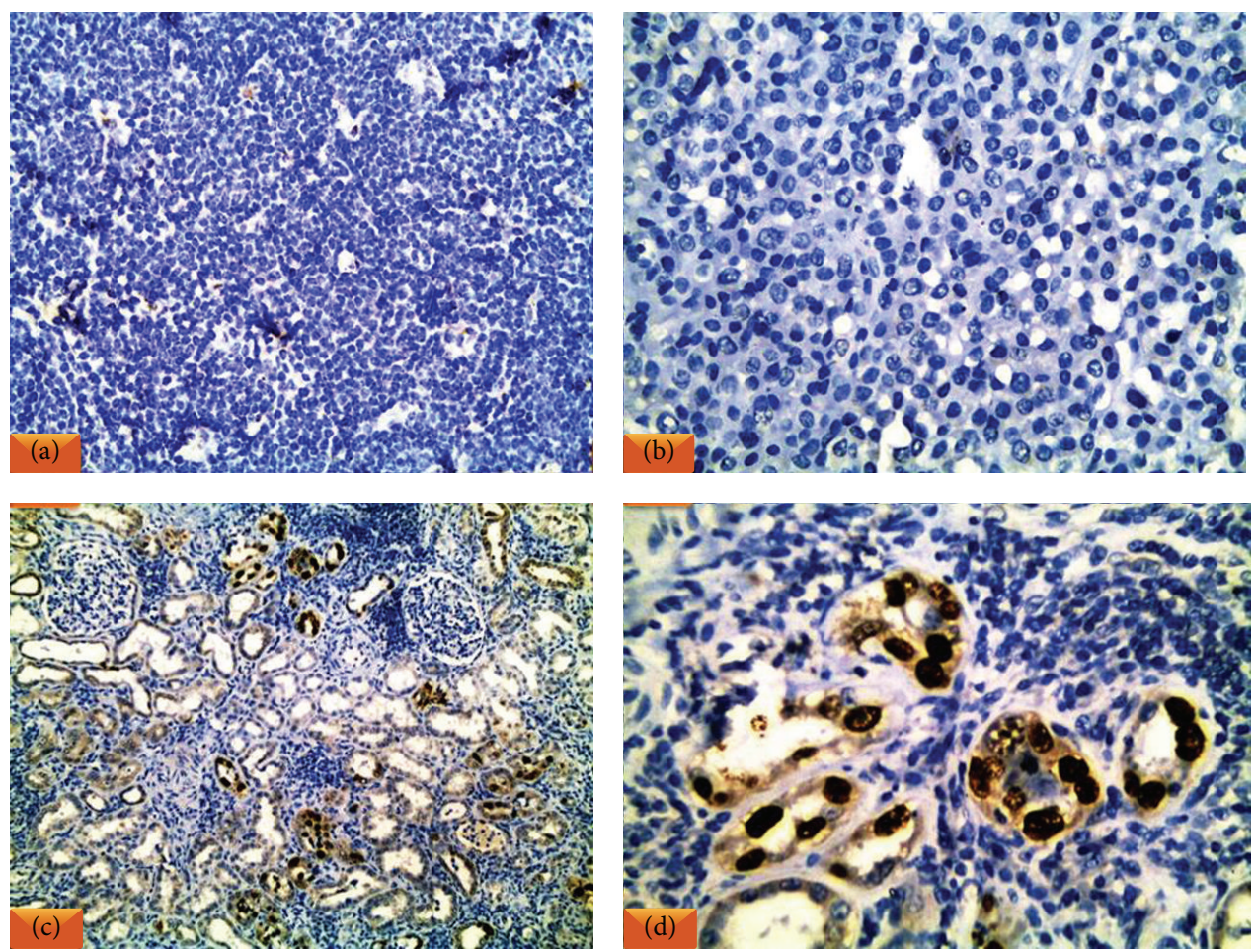

FIGURE 1: (a) Reactive follicular hyperplasia with prominent tangible body macrophages showed SV40 negativity. (b) Diffuse large B-cell lymphoma (DLBCL) displayed SV40 negativity. (c) SV40 infected renal tissue was the positive control. (d) High power view demonstrating the nuclear SV40 positivity in the tubular cells (IHC $\times 200$ for (a) and (c) and $\times 400$ for (b) and (d)).

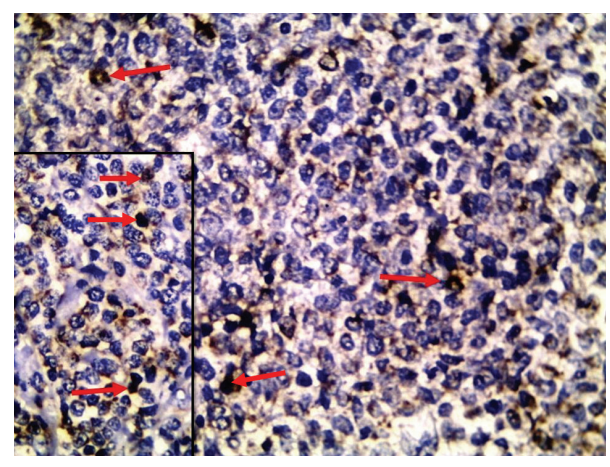

Figure 2: The malignant lymphocytes showed positive nuclear staining (arrows) of SV40 in a case of DLBCL. Inset closer view of nuclear staining of SV40 (arrows) (IHC $\times 400)$.

$71 \%$ of cases with high risk group had high E2F1 expression ( $p=0.049)$. There was no significant association between E2F1 expression and presence of SV40 in DLBCL cases.

(v) Survival analysis of DLBCL cases showed the following.

By univariate survival analysis, $\geq 60$ years age group (log-rank (LR) test $=4.21, p=0.04$ ), worse PS (LR test $=34.94, p<0.001)$ (Figure 5), elevated LDH (LR test $=4.15, p=0.042)$, presence of B symptoms (LR test $=4.9, p=0.027$ ), advanced stage $(\mathrm{LR}=12.19, p<0.001)$, poor prognostic group of R-IPI (LR test $=19.95, p<$ 0.001 ) (Figure 6), high risk group of AAIPI < 60 (LR test $=15.01, p<0.001)$, high Ki-67 LI and apoptotic counts (LR test $=16.93$ and LR test $=12.66$, resp., $p<0.001$ for both), and high E2F1 expression (LR test $=14.99, p<$ 0.001) (Figure 7) had shorter survival time of DLBCL cases. By multivariate survival analysis, E2F1 expression proved to be the most and first independent prognostic factor on overall survival of DLBCL patients $(\mathrm{HR}=5.79,95 \%$ $\mathrm{CI}=2.3-14.6$, and $p<0.001)$.

\section{Discussion}

In Egypt, the high incidence of NHL is possibly related to the exposure of population, at a young age, to various bacterial, parasitic, and viral infections which result in a sustained stimulation of the lymphoid system $[1,14]$. In view of limited and controversial data about SV40 in NHL, we decide to explore the prevalence of SV40 in DLBCL tissue specimens of Egyptian patients. In the current IHC study, 3/85 (4\%) of DLBCL cases were positive for SV40 L-TAG. It was reported that there is no role of SV40 L-TAG in human lymphomas in patients at risk of having received SV40-contaminated poliomyelitis virus vaccines in Italian, Swiss, and Austrian patients [12]. Also, L-TAG was not detected in a lymphoma series of French and Canadian cases as well as in Spanish 
TABLE 2: Descriptive data for SV40 expression in DLBCL.

\begin{tabular}{|c|c|c|}
\hline Variables & $\begin{array}{c}\text { Positive } \\
\text { SV40 } \\
(n=3) \\
\text { No }(\%)\end{array}$ & $\begin{array}{c}\text { Negative } \\
\text { SV40 } \\
(n=82) \\
\text { No }(\%)\end{array}$ \\
\hline \multicolumn{3}{|l|}{ Age } \\
\hline $\bar{x} \pm \mathrm{SD}$ & $31.0 \pm 19.5$ & $55.2 \pm 15.4$ \\
\hline Median & 30.0 & 56.0 \\
\hline Range & $12-51$ & $2-87$ \\
\hline$<60$ & $1(2)$ & $48(98)$ \\
\hline$\geq 60$ & $2(6)$ & $34(94)$ \\
\hline \multicolumn{3}{|l|}{ Gender } \\
\hline Male & $1(2)$ & $41(98)$ \\
\hline Female & $2(5)$ & $41(95)$ \\
\hline \multicolumn{3}{|c|}{ Primary site of involvement } \\
\hline Nodal & $2(4)$ & $54(96)$ \\
\hline Extranodal & $1(3)$ & $28(97)$ \\
\hline \multicolumn{3}{|c|}{ Number of involved extranodal sites } \\
\hline 0 & $1(2)$ & $46(98)$ \\
\hline $1-2$ & $0(0)$ & $32(100)$ \\
\hline$>2$ & $2(33)$ & $4(67)$ \\
\hline \multicolumn{3}{|l|}{ Status } \\
\hline Generalized & $2(12)$ & $14(88)$ \\
\hline Localized & $1(2)$ & $39(98)$ \\
\hline \multicolumn{3}{|l|}{ Size $(\mathrm{cm})$} \\
\hline$\leq 10$ & $2(3)$ & $72(97)$ \\
\hline$>10$ & $1(9)$ & $10(91)$ \\
\hline \multicolumn{3}{|l|}{ Stage grouping } \\
\hline Early & $0(0)$ & $48(100)$ \\
\hline Advanced & $3(8)$ & $34(92)$ \\
\hline \multicolumn{3}{|l|}{ PS } \\
\hline$<2$ & $0(0)$ & $14(100)$ \\
\hline$\geq 2$ & $3(4.2)$ & $68(95.8)$ \\
\hline \multicolumn{3}{|l|}{ B symptoms } \\
\hline Present & $2(4)$ & $49(96)$ \\
\hline Absent & $1(3)$ & $33(97)$ \\
\hline \multicolumn{3}{|l|}{$\mathrm{LDH}$} \\
\hline Normal & $0(0)$ & $11(100)$ \\
\hline Elevated & $3(4)$ & $71(96)$ \\
\hline \multicolumn{3}{|c|}{ Prognostic group of R-IPI } \\
\hline Good & $0(0)$ & $29(100)$ \\
\hline Poor & $3(5)$ & $53(95)$ \\
\hline \multicolumn{3}{|c|}{ Risk groups of AAIPI $\geq 60$} \\
\hline Low & $0(0)$ & $0(0)$ \\
\hline Intermediate & $0(0)$ & $0(0)$ \\
\hline High & $2(14)$ & $0(0)$ \\
\hline \multicolumn{3}{|c|}{ Risk groups of AAIPI $<60$} \\
\hline Low & $0(0)$ & $0(0)$ \\
\hline Intermediate & $0(0)$ & $0(0)$ \\
\hline High & $1(100)$ & $0(0)$ \\
\hline \multicolumn{3}{|l|}{ Type of DLBCL } \\
\hline Germinal & $2(4)$ & $47(96)$ \\
\hline Nongerminal & $1(2.8)$ & $35(97.2)$ \\
\hline \multicolumn{3}{|l|}{ Necrosis } \\
\hline Present & $0(0)$ & $14(100)$ \\
\hline Absent & $3(14)$ & $68(96)$ \\
\hline $\bar{x} \pm \mathrm{SD}$ & - & $\begin{array}{c}34.29 \pm \\
22.43\end{array}$ \\
\hline Range & - & $10.0-80.0$ \\
\hline
\end{tabular}

TABle 2: Continued.

\begin{tabular}{ccc}
\hline & $\begin{array}{c}\text { Positive } \\
\text { SV40 } \\
\text { Variables }\end{array}$ & $\begin{array}{c}\text { Negative } \\
\text { SV40 } \\
\text { No }(\%)\end{array}$ \\
$\begin{array}{ccc}(n=82) \\
\text { No }(\%)\end{array}$ \\
\hline Mitosis & & \\
$\bar{x} \pm$ SD & $21.3 \pm 1.5$ & $22.5 \pm 9.7$ \\
Range & $20-23$ & $6-46$ \\
Media & 21.0 & 21.5 \\
Ki-67 LI & & \\
$<50$ & $3(4)$ & $74(96)$ \\
$\geq 50$ & $0(0)$ & $8(100)$ \\
Apoptosis & & $13.5 \pm 6.5$ \\
$\bar{x} \pm$ SD & $12.7 \pm 3.1$ & $3-31$ \\
Range & $10-16$ & 13 \\
Median & 12 & \\
\hline
\end{tabular}

R-IPI: revised international prognostic index; AAIPI: age adjusted international prognostic index.

PS: performance status; LDH: lactate dehydrogenase; Ki-67 LI: Ki-67 labeling index.

DLBCL: diffuse large B-cell lymphoma.

patients $[15,16]$. Similarly, SV40 L-TAG was detected in $1 / 25$ posttransplant lymphoproliferative disorders and 1/5 AIDS lymphoma in USA [17]. Moreover, weak signals of SV40 L-TAG expression were detected in 12/55 HIV-associated lymphomas in USA and in $4 \%$ of Swiss mesothelioma patients $[18,19]$.

SV40 L-TAG expression in few numbers of DLBCL cases studied might be interpreted by one of the following attributions and theories: (a) absence of the integrated SV40 genome in the host cell and thus absence of permanent expression of the oncoprotein L-TAG $[12,15,16]$, (b) the short half-life of the L-TAG [19], (c) the difference in geographic distribution and incidence of SV40 virus strains [17], (d) an underestimation of viral content as the DNAs recovered from paraffin-embedded tissues are highly fragmented [20], and (e) on the other hand the capability of adopting the "hit and run model" for L-TAG induced transformation claiming that viruses can mediate cellular transformations through an initial "hit" while maintenance of the transformed state is compatible with the loss "run" of viral molecules [21, 22].

Moreover, few polymerase chain reaction (PCR) studies have shown the presence of SV40 in lymphomas with contradicting results. Two Egyptian studies using multiplex nested PCR have shown that SV40 DNA sequences were found in $53.8 \%$ of NHL patients in both series [23,24]. Other studies found $13,10,14,42$, and $43 \%$ incidence of SV 40 in NHL, respectively $[17,25,26]$. However, other studies have not supported these findings [27, 28]. Despite these contradicting results, a recent report concluded that SV40 should be added to the list of factors playing a role in the pathogenesis of B-cell lymphoma, acting together with mutated $\mathrm{p} 53$ in the multistep tumorigenesis of lymphoproliferative disorders [4].

The reasons for the discrepant findings are not clear. You and colleagues assumed that a fascinating possibility of 

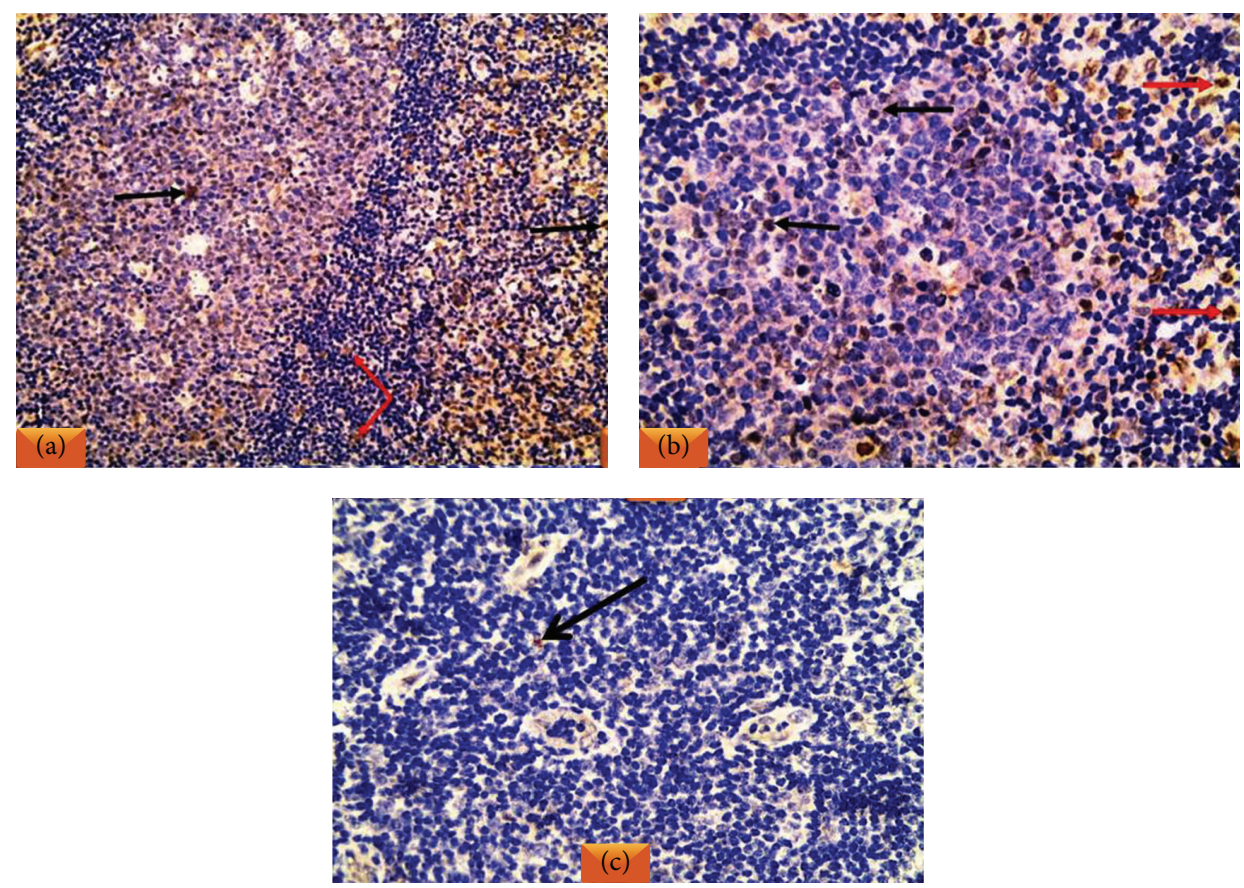

FIgURE 3: (a) A case of reactive follicular hyperplasia showed positive nuclear staining of E2F1 in the lymphocytes in the germinal center (black arrows) and in the interfollicular area (red arrows). (b) High power view of lymphocytes with nuclear positivity in the germinal center (black arrows) and in the interfollicular area (red arrows) together with negative mantle zone lymphocytes. (c) A germinal center exhibited single lymphocyte with nuclear E2F1 positivity (arrow) (IHC $\times 200$ for (a) and $\times 400$ (b) and (c)).
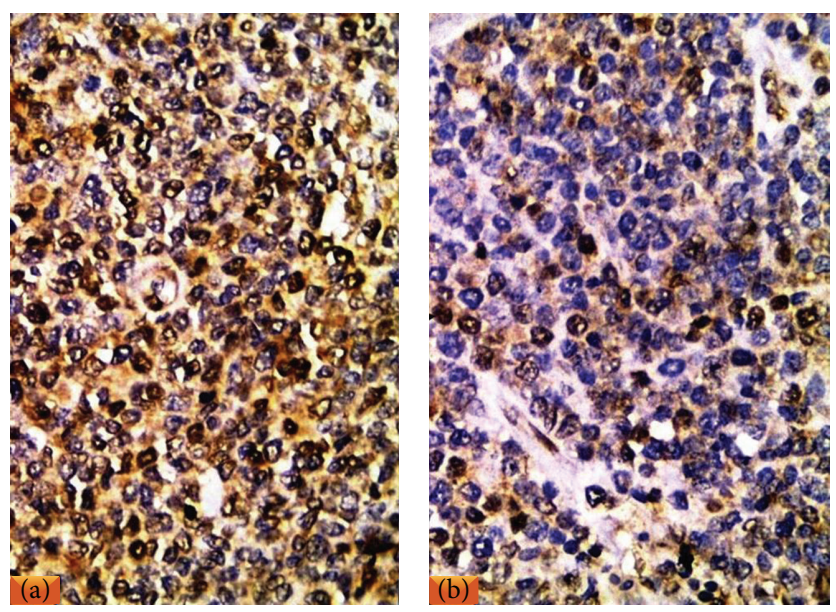

Figure 4: (a) A case of DLBCL showed high nuclear E2F1 expression. (b) A case of DLBCL displayed low nuclear E2F1 expression $($ IHC $\times 400$ for (a) and (b)).

some viral microRNAs (miRNAs) may function as orthologs of cellular miRNAs, but the function of most of them is unknown $[29,30]$. SV40-encoded miR-S1-5p was reported to downregulate the expression of viral T-antigen without reducing the yield of infectious virus, thus reducing host cytotoxic T lymphocyte (CTL) susceptibility and local cytokine release. This dispensable downregulation appears to be very helpful in maintaining the long-term relationship between the virus and the host during latent viral infection or virusmediated tumorigenesis [34]. Nevertheless, the orthologous role of SV40-miR-S1-5p with cellular miR423-5p also implied that SV40-encoded miRNA not only autoregulates its viral gene expression but also may regulate cellular gene expression [29].

The functions and expression of SV40 are a complex process that depends on numerous factors depending on the cellular context, virus host interaction, and accuracy and sufficiency of detection techniques. E2F is a family of transcription factors that regulate the expression of genes involved in a wide range of cellular processes [5]. In the present study, E2F1 was expressed in 5/20 (25\%) of reactive follicular hyperplasia cases mainly localized to the proliferating germinal center and few in the interfollicular areas with complete negativity in the mantle zone lymphocytes. Our results agreed with other reports that stated that E2F1 is a transcription factor that mediates cell-cycle progression from the G1 to $S$ phase and is normally regulated by a group of proteins, including cyclin D1, mainly in the germinal center $[31,32]$.

In the current study all DLBCL cases with high mitosis (high Ki-67 LI) had high E2F1 expression that was consistent with other studies [31,32]. They stated that E2F1 regulates the transcription of many genes necessary for G1/S and G2/M phase transitions, DNA replication, synthesis, and mitosis $[6,31,33]$.

E2F1 modulates cell death via activation of proapoptotic genes and by inactivation of antiapoptotic survival factors through p53-dependent or p53-independent pathways [34] 
TABLE 3: Relationship of E2F1 expression with the clinicopathological data and expression of SV40 in DLBCL cases.

\begin{tabular}{|c|c|c|c|}
\hline \multirow{3}{*}{ Variables } & \multicolumn{2}{|c|}{ E2F1 among DLBCL } & \multirow{3}{*}{$\begin{array}{l}\text { Test of significance and } p \\
\text { value }\end{array}$} \\
\hline & $\begin{array}{c}\leq 10 \\
(n=41)\end{array}$ & $\begin{array}{c}>10 \\
(n=44)\end{array}$ & \\
\hline & No (\%) & No (\%) & \\
\hline \multicolumn{4}{|l|}{ Age } \\
\hline$(\bar{x} \pm \mathrm{SD})$ & $58.5 \pm 6.8$ & $50.4 \pm 14.5$ & \multirow{3}{*}{$\begin{array}{c}t=2.36 \\
0.020^{*}\end{array}$} \\
\hline Median & 69.0 & 56 & \\
\hline Range & $32-75$ & $41-70$ & \\
\hline \multicolumn{4}{|l|}{ Age } \\
\hline$<60$ & $16(33)$ & $33(67)$ & \multirow{2}{*}{$\begin{array}{c}\chi^{2}=11.25 \\
0.001^{* *}\end{array}$} \\
\hline$\geq 60$ & $25(69)$ & $11(31)$ & \\
\hline \multicolumn{4}{|l|}{ Gender } \\
\hline Male & $21(50)$ & $21(50)$ & \multirow{2}{*}{$\begin{array}{c}\chi^{2}=0.10 \\
0.748\end{array}$} \\
\hline Female & $20(47)$ & $23(53)$ & \\
\hline \multicolumn{4}{|c|}{ Primary site of involvement } \\
\hline Nodal & $29(52)$ & $27(48)$ & \multirow{2}{*}{$\begin{array}{c}\chi^{2}=0.83 \\
0.363\end{array}$} \\
\hline Extranodal & $12(41)$ & $17(59)$ & \\
\hline \multicolumn{4}{|c|}{ Number of involved extranodal sites } \\
\hline 0 & $25(3)$ & $22(47)$ & \multirow{3}{*}{$\begin{array}{c}\mathrm{FE}=1.21 \\
0.553\end{array}$} \\
\hline $1-2$ & $13(41)$ & $19(59)$ & \\
\hline$>2$ & $3(50)$ & $3(50)$ & \\
\hline \multicolumn{4}{|c|}{ Status (nodal = 56) } \\
\hline Generalized & $9(40)$ & $9(60)$ & \multirow{2}{*}{$\begin{array}{c}\mathrm{FE}=0.809 \\
0.779\end{array}$} \\
\hline Localized & $17(53)$ & $21(47)$ & \\
\hline \multicolumn{4}{|l|}{ Size $(\mathrm{cm})$} \\
\hline$\leq 10$ & $36(49)$ & $6(51)$ & \multirow{2}{*}{$\begin{array}{c}\chi^{2}=0.04 \\
0.843\end{array}$} \\
\hline$>10$ & $5(45)$ & $38(55)$ & \\
\hline \multicolumn{4}{|l|}{ Stage grouping } \\
\hline Early & $25(52)$ & $23(48)$ & \multirow{2}{*}{$\begin{array}{c}\chi^{2}=0.65 \\
0.419\end{array}$} \\
\hline Advanced & $16(43)$ & $21(57)$ & \\
\hline \multicolumn{4}{|l|}{ PS } \\
\hline$<2$ & $7(50)$ & $7(50)$ & \multirow{2}{*}{$\begin{array}{c}\mathrm{FE}=1.088 \\
1.000\end{array}$} \\
\hline$\geq 2$ & $34(48)$ & $37(52)$ & \\
\hline \multicolumn{4}{|l|}{ B symptoms } \\
\hline Present & $23(45)$ & $28(55)$ & \multirow{2}{*}{$\begin{array}{c}\chi^{2}=0.50 \\
0.478\end{array}$} \\
\hline Absent & $18(53)$ & $16(47)$ & \\
\hline \multicolumn{4}{|l|}{$\mathrm{LDH}$} \\
\hline Normal & $3(27)$ & $8(73)$ & \multirow{2}{*}{$\begin{array}{c}\chi^{2}=2.22 \\
0.136\end{array}$} \\
\hline Elevated & $38(51)$ & $36(49)$ & \\
\hline Prognostic group & & & \\
\hline Good & $14(48)$ & $15(52)$ & $\chi^{2}=0.00$ \\
\hline Poor & $27(48)$ & $29(52)$ & 0.996 \\
\hline Risk groups of A & & & \\
\hline Low & $12(86)$ & $2(14)$ & \\
\hline Intermediate & $5(63)$ & $3(37)$ & $\begin{array}{c}\mathrm{FE}=3.09 \\
0.233\end{array}$ \\
\hline High & $6(55)$ & $5(45)$ & \\
\hline
\end{tabular}


TABLe 3: Continued.

\begin{tabular}{|c|c|c|c|}
\hline \multicolumn{4}{|c|}{ E2F1 among DLBCL } \\
\hline \multirow[t]{2}{*}{ Variables } & $\begin{array}{c}\leq 10 \\
(n=41)\end{array}$ & $\begin{array}{c}>10 \\
(n=44)\end{array}$ & \multirow[t]{2}{*}{$\begin{array}{l}\text { Test of significance and } p \\
\text { value }\end{array}$} \\
\hline & No $(\%)$ & No $(\%)$ & \\
\hline \multicolumn{4}{|c|}{ Risk groups of AAIPI $<60$} \\
\hline Low & $2(15)$ & $11(85)$ & \multirow{3}{*}{$\begin{array}{c}\mathrm{FE}=5.85 \\
0.049^{*}\end{array}$} \\
\hline Intermediate & $10(66)$ & $8(44)$ & \\
\hline High & $6(29)$ & $15(71)$ & \\
\hline \multicolumn{4}{|l|}{ Type of DLBCL } \\
\hline Germinal & $22(45)$ & $27(55)$ & \multirow{2}{*}{$\begin{array}{c}\mathrm{FE}=1.34 \\
0.80\end{array}$} \\
\hline Nongerminal & $18(50)$ & $18(50)$ & \\
\hline \multicolumn{4}{|l|}{ Necrosis } \\
\hline Present & $5(36)$ & $9(64)$ & \multirow{2}{*}{$\begin{array}{c}\chi^{2}=1.05 \\
0.305\end{array}$} \\
\hline Absent & $36(51)$ & $35(49)$ & \\
\hline \multicolumn{4}{|l|}{ Necrosis (\%) } \\
\hline $\bar{x} \pm \mathrm{SD}$ & $44.0 \pm 23.0$ & $28.9 \pm 21.5$ & \multirow{3}{*}{$\begin{array}{c}U=1.15 \\
0.249\end{array}$} \\
\hline Median & 60 & 20 & \\
\hline Range & $10-60$ & $10-80$ & \\
\hline \multicolumn{4}{|l|}{ Mitosis } \\
\hline $\bar{x} \pm \mathrm{SD}$ & $14.5 \pm 4.4$ & $29.9 \pm 6.3$ & \multirow{3}{*}{$\begin{array}{l}\mathrm{U}=12.98 \\
<0.001^{* *}\end{array}$} \\
\hline Median & 13 & 34 & \\
\hline Range & $12-14$ & $24-43$ & \\
\hline \multicolumn{4}{|l|}{ Ki-67 LI } \\
\hline$<50$ & $41(82)$ & $9(18)$ & \multirow{2}{*}{$\begin{array}{r}\chi^{2}=55.44 \\
<0.001^{* *}\end{array}$} \\
\hline$\geq 50$ & $0(0)$ & $35(100)$ & \\
\hline \multicolumn{4}{|l|}{ Apoptosis } \\
\hline $\bar{x} \pm \mathrm{SD}$ & $10.5 \pm 4.9$ & $16.3 \pm 6.4$ & \multirow{3}{*}{$\begin{array}{l}\mathrm{U}=4.29 \\
<0.001^{* *}\end{array}$} \\
\hline Median & 11 & 17 & \\
\hline Range & $4-26$ & $5-25$ & \\
\hline \multicolumn{4}{|l|}{ SV40 } \\
\hline Positive & $1(33)$ & $2(67)$ & \multirow{2}{*}{$\begin{array}{c}\mathrm{FE}=0.28 \\
1.00\end{array}$} \\
\hline Negative & $40(49)$ & $42(51)$ & \\
\hline
\end{tabular}

R-IPI: revised international prognostic index; AAIPI: age adjusted international prognostic index; PS: performance status; LDH: lactate dehydrogenase; ${ }^{*}$ significant; ${ }^{* *}$ highly significant; $t$-test: Student's $t$-test; $U$ : Mann-Whitney test; FE: Fisher's exact test; $\chi^{2}$ : Chi-square test; Ki-67 LI: Ki-67 labeling index; DLBCL: diffuse large B-cell lymphoma.

that is consistent with the current results as DLBCL cases with numerous apoptosis belonged to high E2F1 expression.

E2F1 can stabilize p53 via transcriptional induction of p14ARF, which binds directly to mouse double minutes (MDM2) and inhibits its ability to target p53 for subsequent degradation resulting in p53 accumulation and subsequent activation of its downstream target genes required for apoptosis [6]. A second major mechanism by which E2F1 sensitizes cells to apoptosis is mediated in a p53-independent manner through antiapoptotic signaling mediated by $\mathrm{NF} \kappa \mathrm{B}$ and $\mathrm{Bcl}-2$ [35].

Viral T-antigens can bind all members of the $\mathrm{pRb}$ family promoting the activation of the E2F family, thus inducing the expression of genes required for the entry to the $S$ phase [36]. However, the current study revealed no association between E2F1 expression and presence of SV40 was observed in DLBCL cases. This study offers novel insights into the assumed E2F1 activity that is not seemingly to have a relationship with the accused SV40 in DLBCL of the Egyptian patients.

According to the survival analysis multivariate Cox regression hazard analysis revealed that overexpression of E2F1 is independent prognostic factor for DLBCL cases studied and associated with dismal outcome.

Several reports were concordant with our findings on breast carcinoma, esophageal squamous cell carcinoma, pancreatic ductal carcinoma, non-small-cell lung cancer, and glioblastoma [37-41]. Few reports were in contrast with our findings; low E2F-1 was associated with shortened survival of DLBCL and bladder carcinoma patients [13, 42]. However, squamous cell lung carcinoma cases have no prognostic impact of E2F1 [43]. 

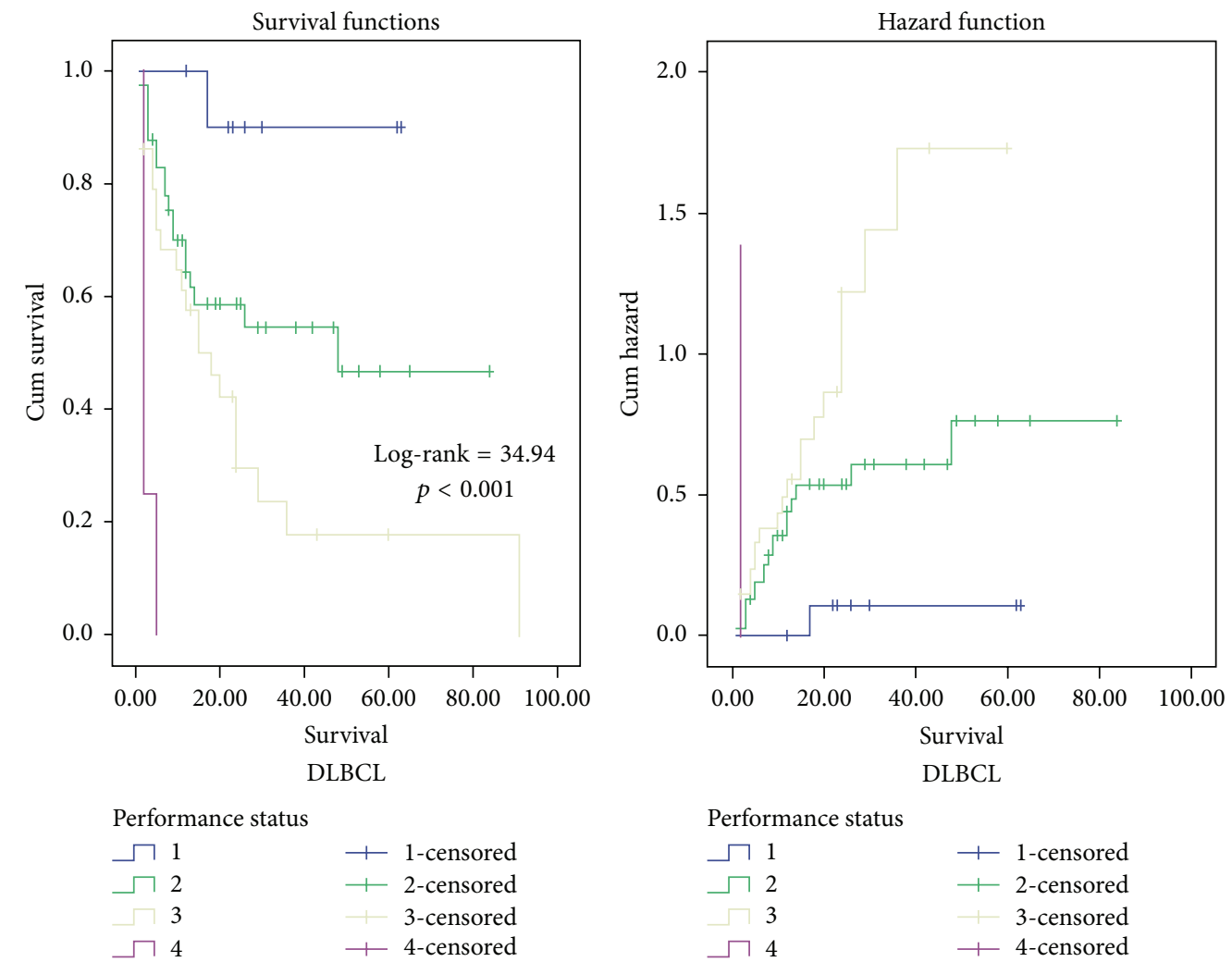

$$
\begin{aligned}
& \begin{array}{ll}
\square 1 & +1 \text {-censored } \\
\square 2 & +1 \text {-censored } \\
\square 3 & 3 \text {-censored }
\end{array} \\
& \neg 4+4 \text {-censored }
\end{aligned}
$$

FIGURE 5: Kaplan-Meier and hazard function curve of overall survival (OS) for DLBCL patients with different categories of performance status (PS) indicating that patients with PS $=4$ were more hazardous.

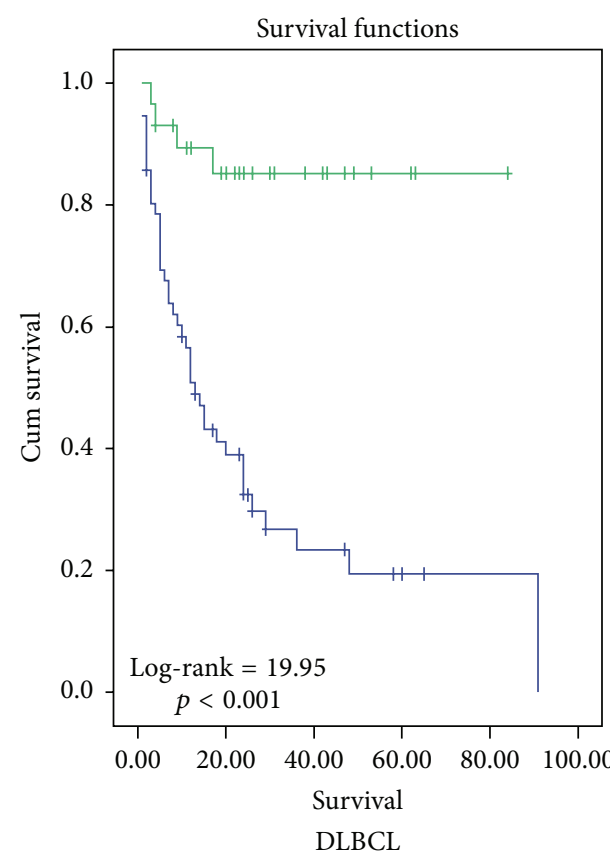

Prognostic group of R-IPI

$\begin{array}{lll}\neg \text { Poor } & + \text { Poor-censored } \\ \square \text { Good } & + \text { Good-censored }\end{array}$

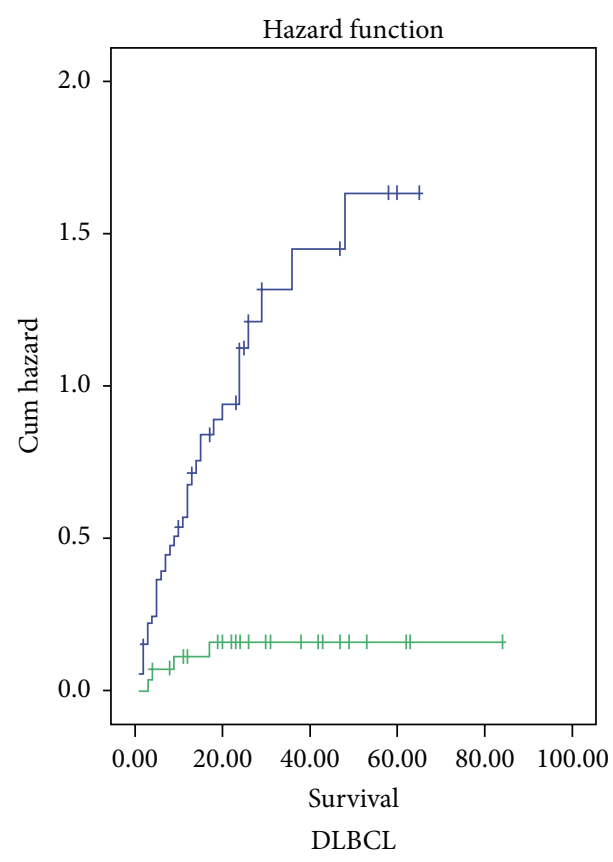

Prognostic group of R-IPI

$\begin{array}{lll}\neg \text { Poor } & + & \text { Poor-censored } \\ \square \text { Good } & + & \text { Good-censored }\end{array}$

FIGURE 6: Kaplan-Meier and hazard function curve of OS for DLBCL patients with different categories of prognostic group of R-IPI indicating that poor prognostic group was more hazardous. 

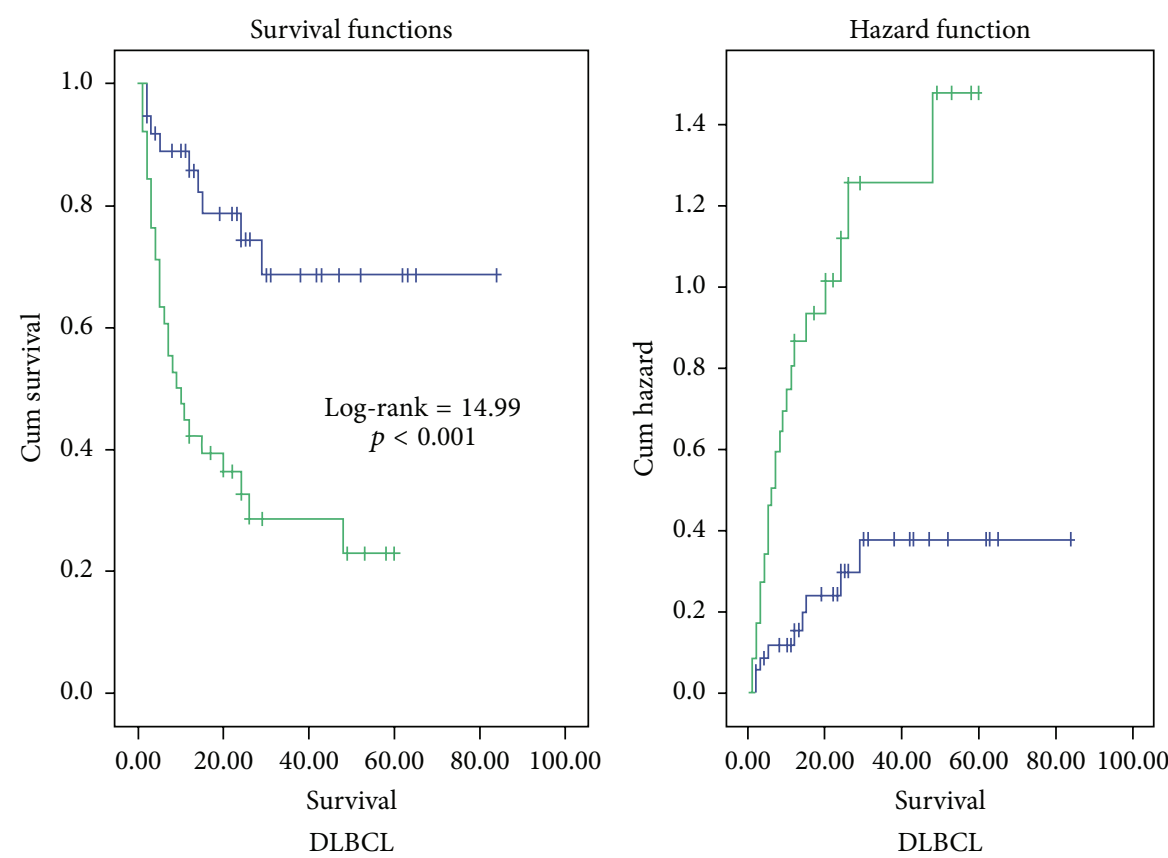

E2F1

E2F1

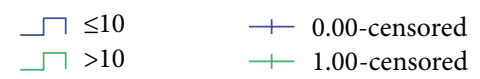

$\neg \leq 10 \quad+0.00$-censored

FIGURE 7: Kaplan-Meier and hazard function curve of OS for DLBCL patients with low and high E2F1 expression indicating that high E2F1 expression was more hazardous.

This dual role of E2F1 in cell-cycle progression and apoptosis gave it the property to be used as a target therapy. Currently, it is hypothesized that the evidence is inadequate to accept or to reject a causal relationship between SV40 and DLBCL in Egyptian patients. E2F1 has a putative oncogenic signaling in DLBCL in the current series by orchestrating and engaging cell death pathways either alone or in cooperation with cellular proliferation pathways. Overexpression of E2F1 is an indicator for short overall survival in DLBCL patients. It is therefore assumed that upregulation of E2F1 has been implicated in oncogenesis, prognosis, and prediction of therapeutic response together with development of novel target therapy. In DLBCL, the assumed E2F1 activity is not seemingly to have a relationship with the accused SV40.

\section{Disclosure}

This paper is original. The requirements for authorship have been met, and each author believes that the paper represents honest work. The paper is not currently under consideration for publication in another journal. This paper has not been published elsewhere and it has not been submitted simultaneously for publication elsewhere.

\section{Disclaimer}

The authors alone are responsible for the content and writing of the paper.

\section{Conflict of Interests}

The authors report no conflict of interests to declare pertaining to this paper.

\section{Authors' Contribution}

All the authors were active participants. This paper has been read and approved by all the authors.

\section{References}

[1] "Epidemiology of cancer," in Pathology of Cancer, M. N. El Bolkainy, M. A. Nouh, I. G. Farahat et al., Eds., chapter 2, pp. 15-31, Cairo Press, Cairo, Egypt, 4th edition, 2013.

[2] A. S. Soliman and P. Boffetta, "Lymphoma and leukemia," in Cancer Incidence in Four Member Countries (Cyprus, Egypt, Israel, and Jordan) of the Middle East Cancer Consortium (MECC) Compared with US SEER, L. S. Freedman, B. K. Edwards, L. A. G. Ries, and J. L. Young, Eds., chapter 14, pp. 131-140, National Cancer Institute, 1st edition, 2006.

[3] G. Barbanti-Brodano, F. Martini, A. Corallini et al., "Reactivation of infectious simian virus 40 from normal human tissues," Journal of NeuroVirology, vol. 10, no. 3, pp. 199-205, 2004.

[4] S. Heinsohn, R. Scholz, and H. Kabisch, "SV40 and p53 as team players in childhood lymphoproliferative disorders," International Journal of Oncology, vol. 38, no. 5, pp. 1307-1317, 2011.

[5] A. K. Biswas and D. G. Johnson, "Transcriptional and nontranscriptional functions of E2F1 in response to DNA damage," Cancer Research, vol. 72, no. 1, pp. 13-17, 2012. 
[6] Z. Wu, S. Zheng, and Q. Yu, "The E2F family and the role of E2F1 in apoptosis," International Journal of Biochemistry and Cell Biology, vol. 41, no. 12, pp. 2389-2397, 2009.

[7] L. H. Sehn, B. Berry, M. Chhanabhai et al., "The revised International Prognostic Index (R-IPI) is a better predictor of outcome than the standard IPI for patients with diffuse large Bcell lymphoma treated with R-CHOP," Blood, vol. 109, no. 5, pp. 1857-1861, 2007.

[8] P. A. Hamlin, A. D. Zelenetz, T. Kewalramani et al., "Ageadjusted International Prognostic Index predicts autologous stem cell transplantation outcome for patients with relapsed or primary refractory diffuse large B-cell lymphoma," Blood, vol. 102, no. 6, pp. 1989-1996, 2003.

[9] A. López-Guillermo, L. Colomo, M. Jiménez et al., "Diffuse large B-cell lymphoma: clinical and biological characterization and outcome according to the nodal or extranodal primary origin," Journal of Clinical Oncology, vol. 23, no. 12, pp. 27972804, 2005.

[10] M. A. Aleskandarany, E. A. Rakha, R. D. MacMillan, D. G. Powe, I. O. Ellis, and A. R. Green, "MIB1/Ki-67 labelling index can classify grade 2 breast cancer into two clinically distinct subgroups," Breast Cancer Research and Treatment, vol. 127, no. 3, pp. 591-599, 2011.

[11] S. Uddin, A. Hussain, M. Ahmed et al., "S-phase kinase protein 2 is an attractive therapeutic target in a subset of diffuse large B-cell lymphoma," The Journal of Pathology, vol. 216, no. 4, pp. 483-494, 2008.

[12] P. Went, C. A. Seemayer, S. Pileri, R. Maurer, A. Tzankov, and S. Dirnhofer, "Lack of protein expression of the simian virus 40 large T antigen in human lymphomas," Journal of Medical Virology, vol. 80, no. 6, pp. 1112-1115, 2008.

[13] M. B. Møller, P. W. Kania, Y. Ino et al., "Frequent disruption of the RB1 pathway in diffuse large B cell lymphoma: prognostic significance of E2F-1 and p16 $6^{\mathrm{INK} 4 \mathrm{~A}}$," Leukemia, vol. 14, no. 5, pp. 898-904, 2000.

[14] "Haematologic malignancy," in Pathology of Cancer, M. N. El Bolkainy, M. A. Nouh, I. G. Farahat et al., Eds., chapter 25, pp. 406-450, Cairo Press, Cairo, Egypt, 4th edition, 2013.

[15] P. Brousset, V. de Araujo, and R. D. Gascoyne, "Immunohistochemical investigation of SV40 large T antigen in Hodgkin and non-Hodgkin's lymphoma," International Journal of Cancer, vol. 112, no. 3, pp. 533-535, 2004.

[16] J. Hernández-Losa, C. G. Fedele, F. Pozo et al., "Lack of association of polyomavirus and herpesvirus types 6 and 7 in human lymphomas," Cancer, vol. 103, no. 2, pp. 293-298, 2005.

[17] P. Rizzo, M. Carbone, S. G. Fisher et al., "Simian virus 40 is present in most United States human mesotheliomas, but it is rarely present in non-Hodgkin's lymphoma," Chest, vol. 116, supplement 6, pp. 470S-473S, 1999.

[18] R. A. Vilchez, D. Lopez-Terrada, J. R. Middleton et al., "Simian virus 40 tumor antigen expression and immunophenotypic profile of AIDS-related non-Hodgkin's lymphoma," Virology, vol. 342, no. 1, pp. 38-46, 2005.

[19] A. Ziegler, C. A. Seemayer, M. Hinterberger et al., "Low prevalence of SV40 in Swiss mesothelioma patients after elimination of false-positive PCR results," Lung Cancer, vol. 57, no. 3, pp. 282-291, 2007.

[20] S. Toracchio, C. A. Kozinetz, D. E. Killen et al., "Variable frequency of polyomavirus SV40 and herpesvirus EBV in lymphomas from two different urban population groups in Houston, TX," Journal of Clinical Virology, vol. 46, no. 2, pp. 154-160, 2009.
[21] K. Khalili, L. Del Valle, J. Otte, M. Weaver, and J. Gordon, "Human neurotropic polyomavirus, JCV, and its role in carcinogenesis," Oncogene, vol. 22, no. 33, pp. 5181-5191, 2003.

[22] L. Ricciardiello, M. Baglioni, and C. Giovannini, "Induction of chromosomal instability in colonic cells by the human polyomavirus JC virus," Cancer Research, vol. 63, no. 21, pp. 7256-7262, 2003.

[23] W. S. Mohamed, M. A. Samra, and M. A. Fawzy, "Presence of simian virus 40 DNA sequences in Egyptian patients with lymphoproliferative disorders," International Journal of Health Sciences, vol. 1, no. 1, pp. 11-16, 2007.

[24] A.-R. Zekri, W. Mohamed, A. Bahnassy et al., "Detection of simian virus 40 DNA sequences in Egyptian patients with different hematological malignancies," Leukemia and Lymphoma, vol. 48, no. 9, pp. 1828-1834, 2007.

[25] F. Martini, R. Dolcetti, A. Gloghini et al., "Simian-virus-40 footprints in human lymphoproliferative disorders of $\mathrm{HIV}^{-}$and $\mathrm{HIV}^{+}$patients," International Journal of Cancer, vol. 78, no. 6, pp. 669-674, 1998.

[26] R. A. Vilchez, C. R. Madden, C. A. Kozinetz et al., "Association between simian virus 40 and non-Hodgkin lymphoma," The Lancet, vol. 359, no. 9309, pp. 817-823, 2002.

[27] S. de Sanjose, K. V. Shah, E. Domingo-Domenech et al., "Lack of serological evidence for an association between simian virus 40 and lymphoma," International Journal of Cancer, vol. 104, no. 4, pp. 522-524, 2003.

[28] J. MacKenzie, K. S. Wilson, J. Perry, A. Gallagher, and R. F. Jarrett, "Association between simian virus $40 \mathrm{DNA}$ and lymphoma in the United Kingdom," Journal of the National Cancer Institute, vol. 95, no. 13, pp. 1001-1003, 2003.

[29] X. You, Z. Zhang, J. Fan, Z. Cui, and X.-E. Zhang, "Functionally orthologous viral and cellular microRNAs studied by a novel dual-fluorescent reporter system," PLoS ONE, vol. 7, no. 4, Article ID e36157, 2012.

[30] C. S. Sullivan, A. T. Grundhoff, S. Tevethia, J. M. Pipas, and D. Ganem, "SV40-encoded microRNAs regulate viral gene expression and reduce susceptibility to cytotoxic T cells," Nature, vol. 435, no. 7042, pp. 682-686, 2005.

[31] J. A. Chan, M. Olvera, R. Lai, W. Naing, S. A. Rezk, and R. K. Brynes, "Immunohistochemical expression of the transcription factor DP-1 and its heterodimeric partner E2F-1 in non-Hodgkin lymphoma," Applied Immunohistochemistry and Molecular Morphology, vol. 10, no. 4, pp. 322-326, 2002.

[32] R. Lai, L. J. Medeiros, R. Coupland, A. McCourty, and R. K. Brynes, "Immunohistochemical detection of E2F-1 in nonHodgkin's lymphomas: a survey of 124 cases," Modern Pathology, vol. 11, no. 5, pp. 457-463, 1998.

[33] A. Blais and B. D. Dynlacht, "Hitting their targets: an emerging picture of E2F and cell cycle control," Current Opinion in Genetics and Development, vol. 14, no. 5, pp. 527-532, 2004.

[34] S. Emmrich and B. M. Pützer, "Checks and balances: E2FmicroRNA crosstalk in cancer control," Cell Cycle, vol. 9, no. 13, pp. 2555-2567, 2010.

[35] J. Stanelle and B. M. Pützer, "E2F1-induced apoptosis: turning killers into therapeutics," Trends in Molecular Medicine, vol. 12, no. 4, pp. 177-185, 2006.

[36] V. Caracciolo, K. Reiss, K. Khalili, G. De Falco, and A. Giordano, "Role of the interaction between large $\mathrm{T}$ antigen and $\mathrm{Rb}$ family members in the oncogenicity of JC virus," Oncogene, vol. 25, no. 38, pp. 5294-5301, 2006. 
[37] V. Vuaroqueaux, P. Urban, M. Labuhn et al., "Low E2F1 transcript levels are a strong determinant of favorable breast cancer outcome," Breast Cancer Research, vol. 9, no. 3, article R33, 2007.

[38] Y. Ebihara, M. Miyamoto, T. Shichinohe et al., "Over-expression of E2F-1 in esophageal squamous cell carcinoma correlates with tumor progression," Diseases of the Esophagus, vol. 17, no. 2, pp. 150-154, 2004.

[39] K. Yamazaki, T. Yajima, T. Nagao et al., "Expression of transcription factor E2F-1 in pancreatic ductal carcinoma: an immunohistochemical study," Pathology Research and Practice, vol. 199, no. 1, pp. 23-28, 2003.

[40] C.-L. Huang, D. Liu, J. Nakano et al., "E2F1 overexpression correlates with thymidylate synthase and survivin gene expressions and tumor proliferation in non small-cell lung cancer," Clinical Cancer Research, vol. 13, no. 23, pp. 6938-6946, 2007.

[41] M. M. Alonso, J. Fueyo, J. W. Shay et al., "Expression of transcription factor E2F1 and telomerase in glioblastomas: mechanistic linkage and prognostic significance," Journal of the National Cancer Institute, vol. 97, no. 21, pp. 1589-1600, 2005.

[42] F. Rabbani, V. M. Richon, I. Orlow et al., "Prognostic significance of transcription factor E2F-1 in bladder cancer: genotypic and phenotypic characterization," Journal of the National Cancer Institute, vol. 91, no. 10, pp. 874-881, 1999.

[43] M. Volm, R. Koomägi, and W. Rittgen, "Clinical implications of cyclins, cyclin-dependent kinases, RB and E2F1 in squamouscell lung carcinoma," International Journal of Cancer, vol. 79, no. 3, pp. 294-299, 1998. 


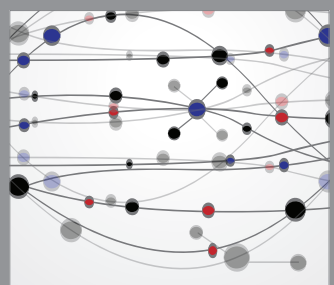

The Scientific World Journal
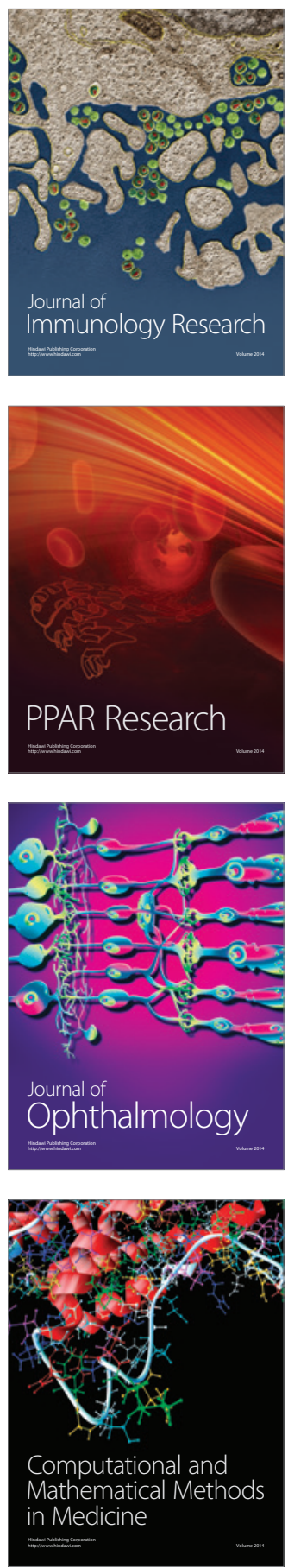

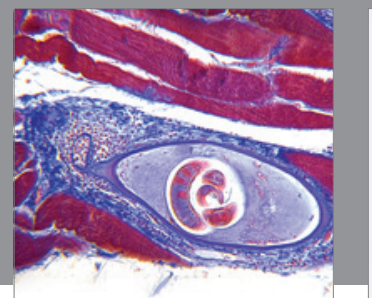

Gastroenterology

Research and Practice
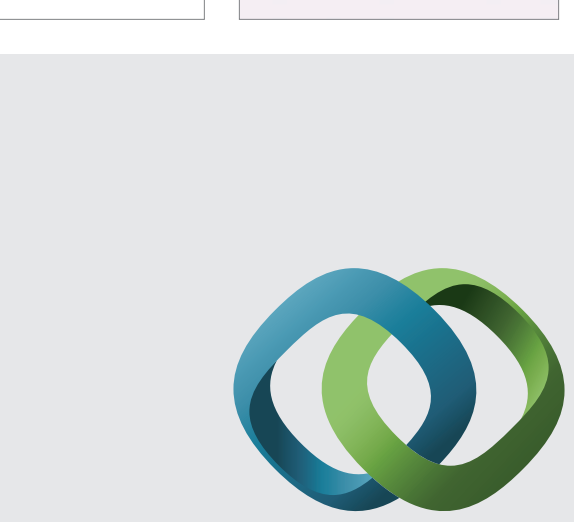

\section{Hindawi}

Submit your manuscripts at

http://www.hindawi.com
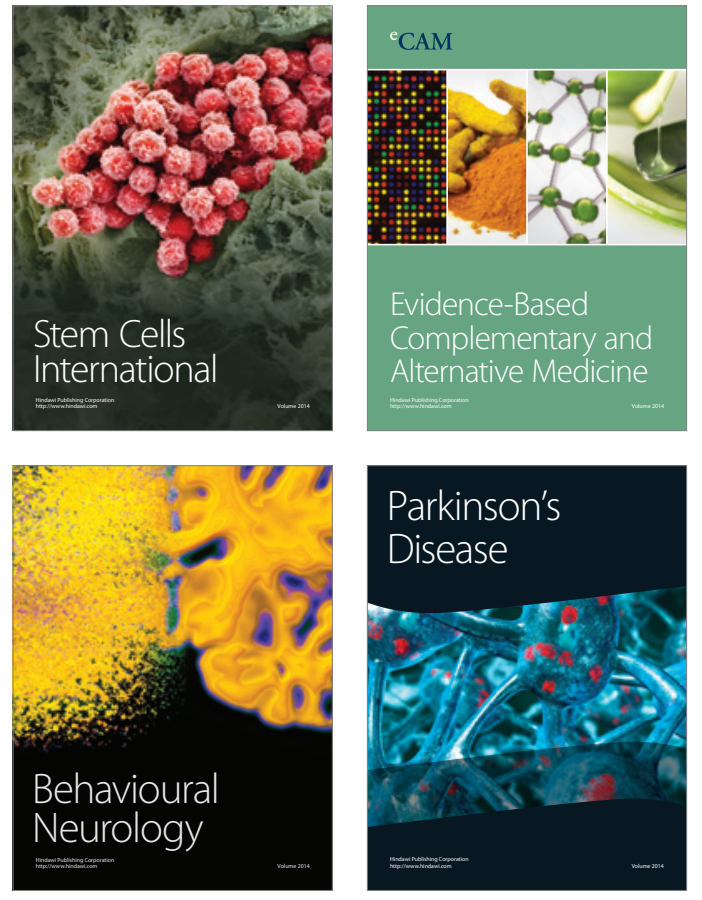
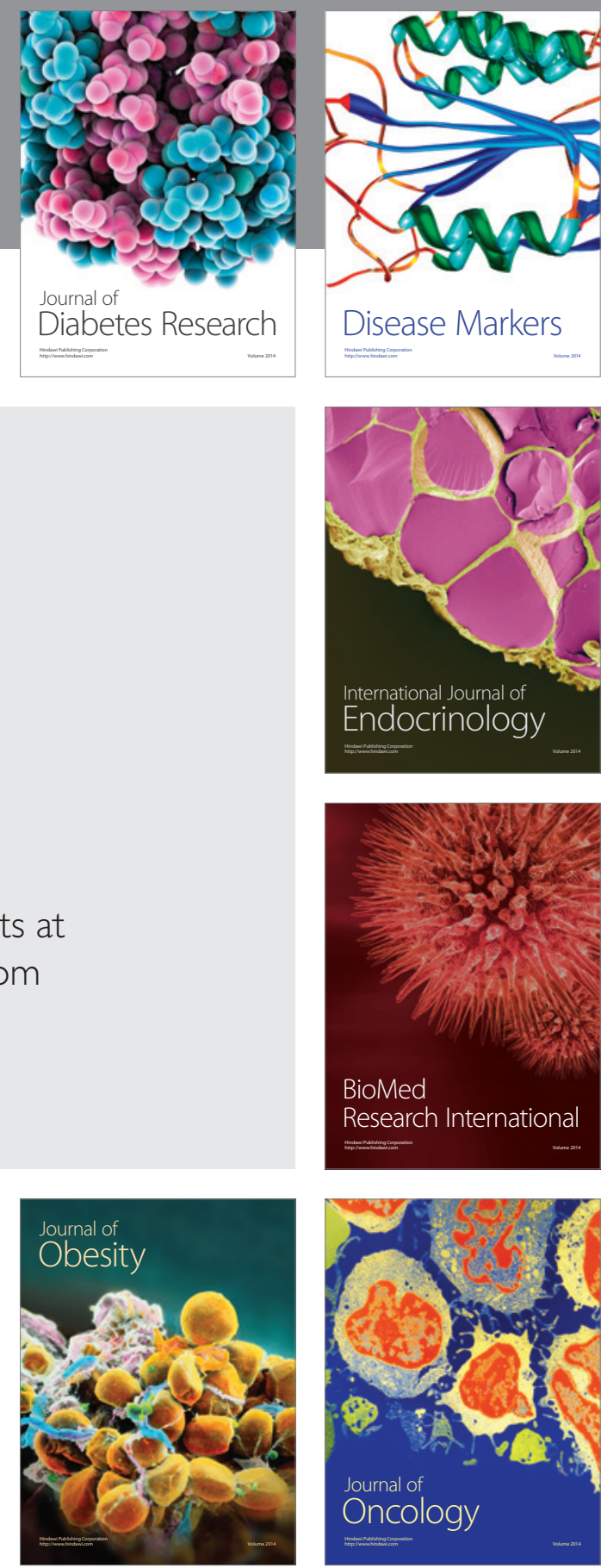

Disease Markers
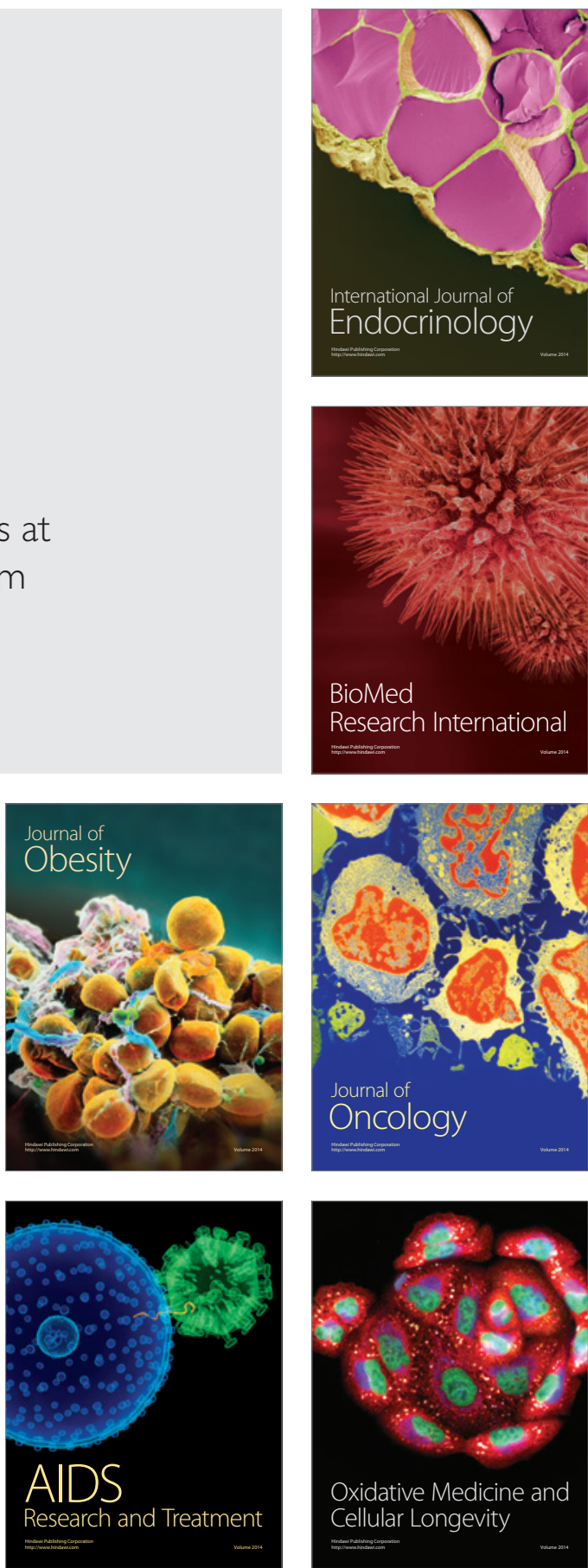